\title{
Interpreting Religious Plurality
}

\subsection{Introduction}

The Indian subcontinent has long been a melting pot of a wide variety of religious traditions. Through the ages religious tolerance has been a hallmark of this multicultural and multi-religious country. However, the resurgence of local cultural and religious consciousness under the influence of modern cultures and the concomitant process of globalization is increasingly complicating the interaction between religious traditions. This tendency in the Indian context is in keeping with an international phenomenon: the politicizing of religious issues and the mushrooming of extreme fanatical wings in various religious traditions. In some ways the global panorama in the new millennium throws the question of religious plurality, into sharp relief. In societies where religious plurality is a given fact people tend to adopt a pragmatic approach to other religions, shaped by their own religious traditions and their particular socio-cultural susceptibility. Hence we can assume that adherents of the three major religions in India have a specific way of interpreting religious plurality.

The general problem considered in this chapter is: how do Christians, Muslims and Hindus interpret religions other than their own? This is a major question that has emerged in what is known as the theology of religions during the last century. In fact, different models of interpreting religious plurality have been identified. We shall reflect on this theory building, paying special attention to pluralist models (5.2). In our opinion the theoretical conceptualization of pluralist models often remains obscure. In outlining our empirical research (5.3) we clarify the structure of our measuring instrument and present the results of the empirical study undertaken among Christian, Muslim and Hindu college students in Tamil Nadu. Finally we discuss salient features of the findings and draw some conclusions about models of interpreting religious plurality $(5 \cdot 4)$.

We have reached a stage in history when it seems almost unethical to think about one's religion in isolation from other religions in the world around us. In the latter half of the 2oth century Christian communities woke up to this

(C) ANTHONY, HERMANS \& STERKENS, 2015 | DOI 10.1163/9789004270862_007

This is an open access chapter distributed under the terms of the Creative Commons AttributionNoncommercial 3.0 Unported (CC-BY-NC 3.0) License. 
imperative explicitly and consciously. Making sense of other religions from the perspective of the Christian faith gave rise to many theologies of religions. ${ }^{1}$ Most authors in this field work with three models: exclusivism, inclusivism and pluralism (cf. D'Costa 1986; Wilfred 1995; Sterkens 2001; Amaladoss 2003; Phan 2004; Vermeer \& Van der Ven 2004; D'Costa, Knitter \& Strange 2011). There seems to be some agreement on the concepts of exclusivism and inclusivism. These two models also have a strong basis in the history of theology. Pluralism, however, is subject to growing debate: are there distinct theological models of pluralism? Does pluralism amount to relativism? Knitter (2002; cf. D'Costa, Knitter \& Strange 2011) sums up various theological trends that shed some light on these questions. He perspicaciously classifies the approaches of Christian communities and theologians into four meaningful models: replacement, fulfilment, mutuality and acceptance. We give a short overview of these models, since they provide the basic framework for our research.

\subsubsection{Replacement}

The replacement model entails exclusive affirmation of one's own religion as the only true religion, hence replacement of all other religions by one's own as the final solution. This approach, which characterized church history up to the 16th century, is epitomized in the famous dictum of the early church fathers, Origen and Cyprian: "Extra ecclesiam nulla salus" (no salvation outside the church). In contemporary Christianity, according to Knitter, Protestant evangelicals and fundamentalists occupy this position. In this model Knitter distinguishes between those who hold out for total replacement and those who recognize a need for partial replacement. The latter group, while acknowledging the possibility of revelation in other religions, denies that they offer salvation. In the contemporary context we realize that similar claims can be made, explicitly or implicitly, by other world religions with a universal view of salvation, such as Islam and Hinduism. In the theological debate this model is generally known as the exclusivist model.

1 The key theological question around which the Christian theologies of religions revolve is the uniqueness and universality of Christ. Besides this Christ-centred focus, Christian theologies of religions generally also have an ecclesiocentric, theocentric, anthropocentric or soteriocentric focus (Thomas 1985; Knitter 1986; D'Costa 1990; Bühlmann 1990; John Paul II 1991; Dupuis 1991; Kuttianimattathil 1995; International Theological Commission 1997; Congregation for the Doctrine of the Faith 2000; Serretti 2004). 


\subsubsection{Fulfilment}

When Christians attempt to combine their affirmation of God's presence in other religions and the non-negotiable aspect of salvation through Christ alone their approach falls under the fulfilment model: other religious traditions will reach their fulfilment in Christianity. This perspective, which was already adopted by some of the early church fathers (Justin Martyr, Tertullian) in their dealings with the Graeco-Roman world, has revived in the mainline churches: Lutheran, Reformed, Methodist, Anglican, Greek Orthodox and Roman Catholic. According to Knitter the pioneering works of Rahner illustrate this trend, which acknowledges that God's grace is active in other religions and views them as possible channels of revelation and salvation. At the same time, since Jesus Christ is God's ultimate revelation and the final source of human salvation, those who receive grace in their own religions are unwittingly oriented to Christianity and hence can be considered 'anonymous Christians'. The documents of the Second Vatican Council (Nostra Aetate 2; Ad Gentes 9, 11, 15, 18) stopped short at this position by acknowledging the presence of 'rays of Truth' and 'seeds of the Word' in other religious traditions, which are thus seen as 'preparation for the Gospel' (Lumen Gentium 16). ${ }^{2}$ Any further concession would jeopardize the non-negotiable uniqueness and universality of Christ. The existence of non-negotiable elements in other religions suggests that the fulfilment perspective is to be found among adherents of other religious traditions as well. In theology of religions this is generally known as the inclusivist model.

The underlying dilemma of religious pluralism is how to reconcile the universality and diversity of religions. All world religions have a universal perspective, and in their particularity or uniqueness give rise to religious diversity. In the replacement and fulfilment models outlined above the accent on the uniqueness and universality of one's own religion is so heavy that all other traditions are either totally or partially invalidated. In other words, these two models have a monistic perspective: the absolute validity of only one religion - one's own. In our research, therefore, we call them replacement monism and fulfilment monism.

2 More recently, the Congregation for the Doctrine of the Faith (2000) writes in its declaration Dominus Iesus (no. 8): "Therefore, the sacred books of other religions, which in actual fact direct and nourish the existence of their followers, receive from the mystery of Christ the elements of goodness and grace which they contain." 


\subsubsection{Mutuality}

Setting aside the non-negotiable elements, the mutuality model prefers to focus on the underlying common elements of which the various religions are diversified expressions and to which they can contribute. To relate across the apparently irreconcilable differences, religions need to discover the shared elements. Knitter describes the mutuality model in terms of three complementary perspectives.

The philosophical-historical perspective highlights the historical limitations of all religions and the philosophical possibility of one divine reality underlying all religions. According to Hick (2003), who represents this trend, lack of a common source or goal would mean that religions are going in different directions. In his view the noumenon is always more than the phenomenon that is accessible to us. In other words, all human knowledge is historically conditioned or socially constructed. Thus different religions point to differences in the manner of experiencing, conceptualizing and living in relation to the ultimate divine reality that transcends the capacity of any one religion. In this sense religious symbols and metaphors represent particular religions rather than define the ultimate divine reality itself. To avoid falling into the trap of relativism, Hick suggests that the value of religions be gauged by the extent to which they promote self-sacrificing concern for the good of others.

The religio-mystical approach proceeds from awareness that religious experience in one's own tradition is limited, while openness is shown to religious experience in other traditions. The religio-mystical approach posits that divine reality is greater than anything that can be experienced in one single tradition, and is accessible in the mystical experiences of various religions. Panikkar's notion of 'cosmotheandric experience' (1993b) is said to exemplify this trend. According to Panikkar mystical experience is based on a necessary interrelationship among three components: the divine, the human and the material world. Although different in many ways, the three cannot exist in isolation from each other. Besides, this divine-human-material interrelatedness is dynamic; it grows and changes. One is called to live out this relationship in ever deeper, life-giving ways in order to further the unfolding of history and the continuation of creation. Insofar as the divine does not exist without the human and the material, the divine itself is as diverse as the religions. Behind the diversity of religions there is this one religious fact. The differences between religions, then, are opportunities for mutual fecundation and growth.

The ethical-practical perspective focuses on the common challenge to alleviate the needs and sufferings of the poor and the oppressed. This global responsibility gives religions an opportunity for understanding themselves and others. The ethical agenda created by human and ecological suffering is 
common to all religions, as recognized by the World Parliament of Religions in 1993 and 1999. It follows that the concept of salvation/liberation which is at the heart of religions, necessarily includes a reference to the human plight and the plight of the planet. The truth and goodness of religions should be measured by their ability to promote peace, justice and unity. As experiences in Basic $\mathrm{Hu}-$ man Communities confirm, involvement in a common liberation process creates an opportunity for understanding each other's religious beliefs.

These three complementary perspectives mean that the mutuality model represents a kind of pluralistic encounter among religions based on underlying - often amorphous - commonalities, which entails a risk of religious relativism. Besides, it tends to disregard the fact that common ground is often identified from the perspective of one's own religious framework. For example, we cannot deny that even the notion of justice - viewed as the responsibility of all religions - is decisively shaped by the Judaeo-Christian cultural tradition. In this sense the model promotes a veiled imperialism. In the theological debate this model is frequently referred to as the pluralistic model. Since it focuses not so much on mutuality as on commonality that allows for pluralism, we prefer to call it commonality pluralism.

\subsubsection{Acceptance}

The commonality pluralism model is so concerned with underlying universal aspects that it tends to disregard the relevance of the particularity or uniqueness of religions. The acceptance model, which according to Knitter is characteristic of the postmodern era, underscores that differences between religions are real and that their particularities are opportunities for reciprocal enrichment and growth. The acceptance model postulates that while different religions can be interrelated, connected and brought into unifying relationships, 'the many' cannot be melted down to 'the one'. The cultural and religious filters are so different that we cannot measure one religion according to the measuring system of another. It is believed that by seeking to remove diversity we will end up destroying the vitality of religions. Knitter identifies three different perspectives in this model: a cultural-linguistic view of religion; pluralism of ultimate concerns; and theological comparison.

Lindbeck (2009) sees the post-liberal cultural-linguistic approach to religion as one of three different ways of understanding religion (the other two being the propositional-cognitive and experiential-expressive perspectives). In the cultural-linguistic perspective religion is viewed as a cultural and/or linguistic framework that shapes one's entire life and thought. In other words, religious experience is shaped by religious language. Our experience is determined by the common religious worldview into which we are born. In this perspective 
there can be nothing truly common to all religions; they refer to different experiences. Religious words and experiences are 'true' only in the given texts or language systems of particular religions. Insofar as religions claim to offer ultimate meaning they serve as a framework for understanding everything else. But this framework cannot be fitted into another framework. What is possible is a kind of dialectical process which can lead to mutual learning and self-correction. Here there is no attempt to impose one's own grand theory on others.

The pluralism of ultimates perspective is represented by S. Mark Heim (1995), who argues that differences between religions go deeper than just language. They reach into the very soul of religions, into their ultimate elements. Religions can be moving towards different destinations or salvations. In the same way differences between religions may also point to differences in the divine ultimate. Real differences between religions open up possibilities for learning something really new. DiNoia (1992) goes a step further: because religious alternatives are sometimes simply not comparable, neither option can be rated as superior to the other. According to him the teachings of a religion or worldview cultivate "a pattern of life" based on its definition of "the true aim" of life as a whole. Conversely, the pattern of life and real-life (e.g. socioeconomic) circumstances help to shape the conceptualization of the aim of life. Since there is no rational basis for preferring one to the other, they can even be described as incommensurable (cf. Sterkens 2001, 73f).

From the perspective of comparative theology, the foundations for a theology of religions are to be found in dialogue rather than in theology itself. According to Clooney $(1996 ; 2010)$ and Fredericks $(1999)$, who represent this trend, a Christian theology of religions must be a comparative theology. Better understanding of one's own religion might follow from a better understanding of others. It requires commitment to one's own religion and at the same time openness to the truths found in others. Comparative theologians are open to the conflict arising from 'double claims' "between our commitments to the Christian tradition, on the one hand, and, on the other, to the allure of other religious traditions" (Fredericks 1999, 169).

The acceptance model with its three complementary perspectives underlines the importance of diversity, but in so doing tends to ignore the underlying common elements shared by the world religions. Given that this model focuses not so much on acceptance as on differences that need to be accepted in a pluralistic context, we prefer to call it differential pluralism. The model that Vermeer and Van der Ven (2004, 43-44) call dialogical pluralism comes close to this model, although its focus is more on the need for dialogue. 


\subsubsection{Relativistic Pluralism}

Knitter (2002:162ff; 224-9) does not describe relativism as a separate model, but refers to a relativistic tendency that can arise in both the mutuality model (commonality pluralism) and the acceptance model (differential pluralism). In his view the philosophical-historical perspective, the religio-mystical perspective and the ethical-practical perspective in commonality pluralism conceal a relativistic tendency, as do the cultural linguistic view, the pluralism of ultimate concerns, and theological comparison in differential pluralism. Relativism thrives on commonalities that tend to be so vague and amorphous as to accommodate anything in its sphere without the need to discern and distinguish underlying nuances and differences. As Knitter $(2002,162)$ puts it with a touch of humour, "Relativists are people for whom the notion of truth is either so broad, or so diversified, or so distant, that they can never trust themselves to know whether they, or anyone, really have the truth. Relativists live in a kind of twilight world in which all cats are grey." Still, commonality pluralism tries to avoid relativism by finding common ground in normative content, and differential pluralism does so by looking at other traditions through their own cultural glasses instead of using one's own. But even in the attempts to avoid it, relativism resurfaces. In the first case one runs the risk of imposing one's normative ideas which are not applicable to others, thus becoming 'imperialistic' (Knitter 2002:163). In the second case any form of critique from an outside perspective becomes impossible (Knitter 2002:225). However, relativism is described as not being necessarily part of pluralism. We therefore discuss it as a separate model.

What is relativism? The Oxford Dictionary (2012) defines it as "the doctrine that knowledge, truth and morality exist in relation to culture, society, or historical context, and are not absolute". This is more descriptive than the meaning the term 'relativism' has sometimes assumed in theological debates. In these debates it is often seen as the impossibility or refusal to make any normative judgments about religious traditions whatsoever. Relativism then becomes a kind of "twilight world in which all cats are grey" (Knitter 2002, 162) or all norms are fair (Cobb 1999:66). Formulated positively, relativism is the attitude of seeing different particular beliefs or complete religious traditions as always equally valid, equally profound and equally humanitarian. Regardless of the question of whether this is a valid definition, we have operationalized 'relativistic pluralism' according to this latter meaning of the word. ${ }^{3}$ Because it is not

3 One could also turn the argument around to a certain degree: plurality is a necessary condition to make moral judgments. Particularly inasmuch as the evaluation of religious traditions and their truth claims form part of dealing with religious plurality, comparison of different tradi- 
necessarily implied in the other forms of pluralism, and since this tendency is expected to be prevalent in the Indian Hindu context, we include it as a distinct model: relativistic pluralism. In the relativistic pluralism model all religions are held to be of equal value and significance, irrespective of common elements and differences that may exist among them.

Thus our theoretical framework comprises five models of interpreting religious plurality, based on a conceptual analysis of Christian theologies of religions, which we hope will prove valid for adherents of other religious traditions as well: replacement monism, fulfilment monism, commonality pluralism, differential pluralism and relativistic pluralism.

\subsection{Empirical Research}

Having clarified the theoretical framework of models of interpreting religious plurality, we now proceed to the empirical phase of our research. First we define the research questions to be investigated from the perspective of our conceptual analysis. Secondly, we describe how the measuring instrument was structured in the conceptual framework of models of religious pluralism. Finally we present the results of the data analysis.

\subsubsection{Research Questions}

In keeping with the conceptual analysis of religious pluralism in the previous section, the research questions are as follows:

(1) Which comparative models of interpreting religious plurality are found among Christian, Muslim and Hindu students once group-specific differences have been ascertained?

(2) Are there significant differences in the levels of agreement with the comparative models of interpreting religious plurality between Christian, Muslim and Hindu students?

(3) Which personal (socio-cultural, socio-economic and socio-religious) characteristics relate to the level of agreement with the comparative models of interpreting religious plurality?

tions in terms of a meta-theory is essential. Here comparison - that is looking for common ground or weighing advantages and disadvantages of different approaches - is seen as a vital condition for, rather than an obstacle to, normative judgment (cf. Sterkens 2009, 258; Wils 2005). 
(4) Which personal characteristics may be considered predictors of models of interpreting religious plurality among Christian, Muslim and Hindu students?

\subsubsection{Measuring Instruments}

The questionnaire distributed in our research deals with the five models of interpreting religious plurality derived from Christian theology of religions: replacement monism, fulfilment monism, commonality pluralism, differential pluralism and relativistic pluralism. Each model is represented by four indicators referring to four basic dimensions. Each dimension is formulated on a general level, that is to say, the formal status of the dimensions is the same in each religion, although the language, ideas and symbols representing the ultimate referents in these religions can be very different (Vroom 2003). ${ }^{4}$ Three of the indicators represent the basic dimensions of religions and the fourth refers to the overall relationship of that religion with the others. Formally each religion is characterized by three basic dimensions: experiential, normative and transformative. The experiential dimension reflects the human being's experience of ultimate reality (God), the normative dimension refers to the truth claim of the religious tradition, and the transformative dimension relates to the adherent's becoming or self-realization. The tendencies in these three dimensions shape the overall relational dimension - the relationship of one religion with others. In the fulfilment monism model, for example, the dimensions are operationalized as follows: "Other religions do not offer as deep a God-experience (anubhava) as my religion" (experiential dimension); "Compared with my religion, other religions contain only partial truths" (normative dimension); "Compared with other religions, my religion offers the surestway to liberation (salvation, mukti, paradise)" (transformative dimension); "Other religions will eventually find their fulfilment in mine" (relational dimension). Since this is a comparative study of Christian, Muslim and Hindu students, we had to be careful to use general categories without losing sight of the nuances of specific categories in each religion. We tried to resolve this in the following ways.

In operationalizing the experiential dimension we included in brackets the term 'anubhava', meaning 'God-experience' or 'experience of God'. Anubhava is a Sanskrit term used in most Indian languages, including Tamil. In the Hindu tradition of Sankara it refers to the integral mystical experience in which all thinking is nullified and the knowing subject becomes one with the object of

4 Jensen distinguishes four modes of comparison: form, function, structure and meaning (Jensen 2003,124-125). The four dimensions used in each model fall in the category of function of religion in the life of individuals and communities. 
knowledge (advaita). The term has a strong cultural resonance in all religious traditions in India, be it Christianity, Islam or Hinduism. Although the term is applicable to all three religious traditions under investigation, we do not claim that its use solves all difficulties of comparison (cf. Van der Zwan 1994, 128; Panikkar 1993, 120-133; Le Saux 1982, 161-175; Samartha 1991, 103-111).

The normative dimension (referring to the truth claim of religions) and the relational dimension were operationalized abstractly and generically. Thus the overall relationship among religions implied in the five models was formulated as follows: "Eventually my religion will replace other religions" (replacement monism); "Other religions will eventually find their fulfilment in mine" (fulfilment monism); "The similarities among religions are a basis for building a universal religion" (commonality pluralism); "Differences between religions are a basis for mutual enrichment and growth" (differential pluralism); and "Although there are many religions, at the deepest level there are no real differences" (relativistic pluralism).

To represent the transformative dimension we used terms specific to each religion. Although the ultimate transformation proposed by religions can be expressed by the general abstract term 'liberation', we included in brackets the terms for ultimate transformation in each religion so as to evoke its specific meaning in that tradition: 'salvation' in the case of Christianity, 'paradise' in the case of Islam, and 'mukti' in the case of Hinduism.

Following this scheme, each of the five models of interpreting religious plurality was operationalized in four items, to which respondents indicated their agreement on a four-point Likert scale from disagreement (1) to agreement (4). Thus our measurement instrument for models of interpreting religious plurality comprised a total of 20 items: replacement monism (items 1, 4, 6 and 19), fulfilment monism (items 3, 5, 8 and 10), commonality pluralism (items 7, 9, 12 and 14), differential pluralism (items 11, 13, 16 and 18) and relativistic pluralism (items 2, 15, 17 and 20). See appendix E for a complete list of the items.

We assumed these models of interpreting religious plurality to be logical options in each of the religions under investigation. Establishing the extent to which people actually subscribe to these ideas is the aim of our research. For example, the premise of the commonality pluralism model is that all religions refer to the same ultimate reality. In Christianity the main exponent of this model is Hick, but there are modern Hindu and Islamic scholars who seem to have much the same idea. Fredericks $(1995,74)$ cites Bithika Mukerji, who refers to a universal religious experience common to all religions: "Christianity in the reflection of Hinduism is yet another dimension in which God has disclosed himself to his People" (Mukerji 1990, 233). In modern Islam he quotes Mohamed Talbi $(1990,101)$, who, reflecting on the dialogue between Islam and 
Christianity, affirms: "Thus when all is said and done, we find ourselves faced with the unfathomable mystery of God's Plan and of man's condition." From these examples one concludes that the underlying idea of the commonality pluralism model as formulated in terms of Christian theology of religions is not completely alien to recent developments in Hinduism and Islam.

\subsubsection{Empirical Results}

The results of the data analysis provide answers to the four research questions that define the scope of our research. We deal with them one by one, presenting the results pertaining to each.

Research question 1: Which comparative models of interpreting religious plurality are found among Christian, Muslim and Hindu students once groupspecific differences have been ascertained?

For the construction of comparative models of interpreting religious plurality, we followed the analysis procedure described in more detail in chapter 1 (1.7). We present the results of the third step: the factor analysis conducted on all students after filtering out differences between the three religious groups, followed by the test for scalar invariance in which factor models are evaluated by means of JRule. Then we describe the differences between the religious groups that were filtered out after the second step. Table 5.1 shows the Principal Axis Factoring (Oblimin rotation method) of 13 of the 20 items in our questionnaire. In total seven items were removed in previous steps, either because of low commonalities (items 11 and 18) or multiple loading (items 15 and 17) in the first factor analysis for the whole sample, or because some items $(12,16$ and 20) proved to be peculiar to one of the groups in the second factor analysis. The final factor analysis results in a total explained variance of $52,4 \%$ for the whole sample, and remains almost unaltered when Christians (51,5\%) and Muslims $(52,4 \%)$ are examined separately, while it is lower for Hindus $(43,8 \%)$.

Contrary to expectation, four items meant to represent replacement monism and three items representing fulfilment monism cluster together under factor 1 . The two models share a monistic view of religion, namely belief in the universal validity of one's own religion only. The two items ( 5 and 10) with the highest factor loading belong to the fulfilment model, which is a milder form of monism than the replacement model. Accordingly we label factor 1 monism ( $\alpha$ .90) with a certain emphasis on fulfilment. ${ }^{5}$

5 A similar clustering of exclusivism and inclusivism was found in Vermeer and Van der Ven (2004). 
Factor 2 covers four items, three of which (7, 9 and 14) are meant to represent commonality pluralism and one (item 2 ) relativistic pluralism. The item with the highest factor loading clearly represents the model of commonality pluralism. Item 2 can also be understood in a non-relativistic way, if we assume that respondents put the accent less on 'equally' and more on 'profound experience of God'. Hence we retain the name commonality pluralism ( $\alpha$.79) for this factor. At the same time we have to take into account that one item of the commonality model - the one referring to building a universal religion (item 12) had to be eliminated after the second step of our analysis. This suggests that acceptance of commonality among religions does not necessarily imply universal commonality or moving towards a common religion. We shall deal with this question in our discussion.

Factor 3 contains two items (13 and 16) that represent differential pluralism $(\alpha .38)$. These two items suggest the necessity of accepting differences between religions as part of God's plan to save the world and as an opportunity for reciprocal enrichment and growth. In the final section we try to explain why the other two items (11 and 18) did not load on this factor.

Through confirmatory factor analysis we tested whether the measurement models are the same for all groups, also whether the factor loadings are the same across groups. Analysis of the data with Lisrel 8.8 (Jöreskog \& Sörbom 2012) resulted in an acceptable model fit for the test of scalar invariance for monism $\left(\mathrm{X}^{2}[\mathrm{df}=88]=376.78\right.$; $\mathrm{RMSEA}=.073$; $\left.\mathrm{GFI}=.95\right)$. This means that we can assume that the measurement is equivalent for the three different religious groups (Christian, Muslims and Hindus), and allows meaningful comparison of monism between these groups. We also tested for scalar invariance for commonality pluralism and differential pluralism. ${ }^{6}$ The initial model was rejected $\left(\mathrm{X}^{2}[\mathrm{df}=36]=124.57\right.$, RMSEA $=.063$; GFI $\left.=.98\right)$, because there were 2 misspecifications in the intercepts of the items. We improved the model by freeing the intercepts of the third item of commonality pluralism (i.e. item 2) and the second item of differential pluralism (i.e. item 16) for Hindus. The resulting model was accepted $\left(\mathrm{X}^{2}[\mathrm{df}=34]=71.19, \mathrm{RMSEA}=.042 ; \mathrm{GFI}=.98\right)$. These results indicate that the scale to measure commonality pluralism is partially invariant (Byrne, Shavelson, and Muthén, 1989). The scale to measure 'differential pluralism' is not scalar invariant for Hindus, but it is metric invariant, implying that we cannot compare the mean on this scale for Hindus with other religions, but we can compare the relationship of this scale with other metric or scalar invariant measures across religions (see also section 2.6 on levels of equivalence).

6 Because we cannot test for scalar invariance based on 2 items, we tested for scalar invariance for commonality pluralism ( 4 items) and differential pluralism (2 items) simultaneously. 
TABLE 5.1 Factor analysis (PAF, Oblimin rotation), commonalities $\left(h^{2}\right)$, percentage of explained variance, and reliability (Cronbach's alpha) of comparative models of interpreting religious plurality among Christian, Muslim and Hindu students.

\begin{tabular}{|c|c|c|c|c|}
\hline & F1 & F2 & $\mathrm{F}_{3}$ & $\mathbf{h}^{2}$ \\
\hline $\begin{array}{l}\text { 5. Compared with other religions, my religion offers the } \\
\text { surest way to liberation (salvation, mukti, paradise). }\end{array}$ & .81 & .01 & -.01 & .63 \\
\hline $\begin{array}{l}\text { 10. Other religions do not offer as deep a God-experience } \\
(\text { anubhava) as my religion. }\end{array}$ & $\cdot 77$ & -.01 & .01 & .62 \\
\hline $\begin{array}{l}\text { 3. Compared with my religion, other religions contain } \\
\text { only partial truths. }\end{array}$ & $\cdot 72$ & -.01 & .01 & .54 \\
\hline $\begin{array}{l}\text { 1. Only through my religion people can attain true } \\
\text { liberation (salvation, mukti, paradise). }\end{array}$ & .69 & -.12 & -.01 & .57 \\
\hline $\begin{array}{l}\text { 6. Other religions do not offer a true experience of God } \\
(\text { (anubhava). }\end{array}$ & .69 & -.13 & .01 & .60 \\
\hline 4. Eventually my religion will replace other religions. & .69 & .12 & .01 & .40 \\
\hline $\begin{array}{l}\text { 7. Different religions reveal different aspects of the } \\
\text { same ultimate truth. }\end{array}$ & .01 & .81 & .01 & .58 \\
\hline $\begin{array}{l}\text { 9. Every religion contributes in a unique way to the } \\
\text { ultimate liberation of human beings (salvation, } \\
\text { mukti, paradise). }\end{array}$ & .01 & .68 & .01 & .46 \\
\hline $\begin{array}{l}\text { 2. All religions provide an equally profound experience } \\
\text { of God (anubhava). }\end{array}$ & -.20 & .58 & -.01 & .56 \\
\hline $\begin{array}{l}\text { 14. Different aspects of the same divine reality are } \\
\text { experienced in different religions. }\end{array}$ & -.01 & .55 & -.15 & .43 \\
\hline $\begin{array}{l}\text { 13. Differences between religions are part of God's plan } \\
\text { to save the world. }\end{array}$ & .01 & .01 & -.64 & .41 \\
\hline 16. Differences between religions are a basis for mutual & -.01 & .01 & -.62 & .42 \\
\hline Cronbach's alpha & .90 & .79 & .38 & \\
\hline Number of valid cases & 1869 & 1873 & 1894 & \\
\hline
\end{tabular}

Scale: $1=$ disagree; $2=$ tend to disagree; $3=$ tend to agree; $4=$ agree Explained variance $=52,4 \% ; \mathrm{F} 1=$ Monism; F2 $=$ Commonality pluralism; F3 $=$ Differential pluralism; $\mathrm{N}=1920$.

As said before, the factor analysis for the whole sample in the third step was only conducted after investigating the three religious groups separately and included only items that appeared in all three religious groups. It is worth looking at the results of factor analyses in the second step to account for the differences between the religious groups. The separate factor analysis for Christians reveals that the items for fulfilment monism have the highest factor loadings in 
the monism model. An item that typically refers to fulfilment concerns the Christian monism factor: "Other religions will eventually find their fulfilment in my religion" (item 8), but is not part of the comparative monism measurement. It suggests that Christian monism has a strong fulfilment tendency. Unlike the comparative measurement, the commonality pluralism factor includes an item expressing the relativistic view that there are no real differences between religions: "Although there are many religions, at the deepest level there are no real differences" (item 20). Considering that commonality pluralism contains another item with a relativistic tendency (item 2), we conclude that Christian commonality pluralism tends towards relativism. Unlike commonality pluralism, the configuration of Christian differential pluralism is no different from the configuration of this factor for the whole sample.

The factor analysis for Muslims shows that the monism model emerges in all eight items (as in the case of Christians). However, the items representing fulfilment and replacement monism do not cluster in higher and lower factor loadings respectively. Does this imply that in affirming the exclusive validity of one's own religion absolutely no distinction is made between 'weak' and 'strong' forms of monism? The commonality pluralism and differential pluralism factors contain the same items as the comparative models.

The factor analysis for Hindus yields the same result for the monism model as that for Muslims: the items representing the replacement and fulfilment models are jumbled together. The items in differential pluralism are the same as in the comparative model. The main differences found among Hindus pertain to commonality pluralism. Firstly, the Hindu understanding of commonality pluralism includes the idea of building a universal religion (item 12: "The similarities among the religions are a basis for building up a universal religion"). Secondly, like Christians, they include the relativistic view that at the deepest level there are no real differences between religions (item 20). Inclusion of these two items suggests a strong universalistic and relativistic tendency in Hindu commonality pluralism.

In general we might say that the comparative models seem to fit Muslims best (with only item 8 in the monism factor filtered out), followed by Christians (without item 8 for monism and item 20 for commonality pluralism) and Hindus (without items 12 and 20 for commonality pluralism). This is mirrored by the percentages of explained variance for the separate factor analyses among Muslims (52,4\%), Christians and Hindus $(43,8 \%)$.

Research question 2: Are there significant differences in the levels of agreement with the comparative models of interpreting religious plurality between Christian, Muslim and Hindu students? 
TABLE 5.2 Levels of agreement (mean and standard deviation) with regard to monism for Christian, Muslim and Hindu students; and comparison of means between religious groups of respondents (Scheffe's test: F-value: 309.42 ; sign.<.ooo).

\begin{tabular}{llllll}
\hline & N & Mean & S.d. & Muslims & Hindus \\
\hline Christians & 849 & 2.76 & .91 & & $* *$ \\
Muslims & 241 & 2.89 & .98 & & $* *$ \\
Hindus & 773 & 1.79 & .76 & $* *$ & \\
\hline
\end{tabular}

Scale: $1=$ disagree; $2=$ tend to disagree; $3=$ tend to agree; $4=$ =agree. Intergroup differences are significant at $\mathrm{p}<.000\left({ }^{* *}\right)$ or $\mathrm{p}<.005$ level $\left({ }^{*}\right)$.

To answer the second research question we compare agreement with the three comparative models of interpreting religious plurality among Christians, Muslims and Hindus and use Scheffé's test to determine whether the differences are significant. ${ }^{7}$

With regard to the monism model there are great differences between the three groups. Christians are generally doubtful about monism, although their ambivalence tends towards agreement (2.76). Muslims agree with the monism model (2.89) and Hindus generally disagree with it (1.79). Hindus, who favour the monism model least, differ significantly from both Christians and Muslims. The difference between Christians and Muslims is not significant (Table 5.2).

The three groups' mean scores for commonality pluralism fall in the area of positive agreement. In a multi-religious context it seems reasonable to expect religions to share some fundamental features. Although the three groups agree with commonality pluralism, Hindu respondents (3.37) differ significantly from both Christians (3.02) and Muslims (2.93) in that they seem to be most open to the underlying commonality of religions (Table 5.3).

The three groups' mean scores for differential pluralism fall in the area of doubt. Hindus (2.70) and Christians (2.62) tend towards agreement, whereas Muslims (2.50) are ambivalent. However, there are no significant differences between the religious groups. We note that the attitude towards differential pluralism is very different from the level of agreement with commonality

7 We interpret the means as follows: scores between 1 and 2.20 are interpreted as disagreement, scores between 2.21 and 2.80 as doubt, and scores between 2.81 and 4.00 as agreement. The rationale behind this interpretation is that the middle of the scale $\left(2.5^{\circ}\right)$ does not tells us whether respondents agree or disagree with a model. We used a four-point Likert scale without a middle category: (1) Disagree, (2) Tend to disagree, (3) Tend to agree, (4) Agree. 
TABLE 5.3 Levels of agreement (mean and standard deviation) with regard to commonality pluralism for Christian, Muslim and Hindu students; and comparison of means between religious groups of respondents (Scheffés test: F-value: 49.30 ; sign. <.ooo).

\begin{tabular}{llllll}
\hline & N & Mean & S.d. & Muslims & Hindus \\
\hline Christians & 848 & 3.02 & .88 & & $* *$ \\
Muslims & 241 & 2.93 & .85 & & $* *$ \\
Hindus & 777 & 3.37 & .74 & $* *$ & \\
\hline
\end{tabular}

Scale: $1=$ disagree; $2=$ tend to disagree; $3=$ tend to agree; $4=$ =agree. Intergroup differences are significant at $\mathrm{p}<.000$ level $\left({ }^{* *}\right)$.

pluralism. How do we explain this difference? Differential pluralism implies active involvement in religious differences, illustrated by, for instance, item 16: "differences $[\ldots]$ are a basis for mutual enrichment and growth". Active involvement is certainly more demanding than recognition of commonality in Godexperience or ultimate truth. Besides, the average score in the area of doubt and the relatively high standard deviations for differential pluralism may indicate that there is dissent in the religious groups about differential pluralism (Table 5.4). When we calculate the percentages of scores representing disagreement (1-2.20), doubt (2.21-2.80) and agreement (2.81-4.00) among Christians, Muslims and Hindus, it is revealing that almost half the Christians (47.8\%) and Hindus (49.7\%) agree with differential pluralism, while one third of these groups disagrees with it (Christians $33.2 \%$, Hindus 31.8\%). Among Muslims equally large proportions either agree $(41.4 \%)$ or disagree $(40 \%)$ with differential pluralism. Opposite trends with regard to the differential pluralism model seems to be strongest among Muslims. These figures illustrate that differential pluralism is indeed disputed.

Research question 3: Which personal (socio-cultural, socio-economic and socio-religious) characteristics relate to models of interpreting religious plurality among Christian, Muslim and Hindu college students?

This question concerns the social location of the models of interpreting religious plurality. We discuss the models of monism, communality pluralism and diversity pluralism successively. For each model we give the significant correlations with the personal characteristics of our Christian, Muslim and Hindu respondents. 
TABLE 5.4 Levels of agreement (mean and standard deviation) with regard to differential pluralism for Christian, Muslim and Hindu students; and comparison of means between religious groups of respondents (Scheffé's test: F-value: 4.73 ; sign. =.oog).

\begin{tabular}{llllll}
\hline & N & Mean & S.d. & Muslims & Hindus \\
\hline Christians & 862 & 2.62 & .96 & \\
Muslims & 245 & 2.50 & .96 & \\
Hindus & 780 & 2.70 & .92 & \\
& & & & \\
\hline
\end{tabular}

Scale: $1=$ disagree; $2=$ tend to disagree; $3=$ tend to agree; $4=$ agree. There are no significant intergroup differences at $\mathrm{p}<.005$ level.

\section{Monism}

Among Christian students there are relatively low but significant associations with three socio-cultural characteristics: language (.15), urbanization (.11) and gender (.07). Christian students whose mother tongue is Tamil (2.83) score higher on monism than students who don't speak Tamil (2.50); agreement with monism is relatively stronger in urbanized areas; and - surprisingly - Christian women (2.81) on average have a stronger monistic orientation than men (2.69), although the association is low and of limited significance $(\mathrm{p}<.05)$. A positive personal evaluation of the influence of mass media (.17) and the religious community (.13) correlates positively with monism among Christians. The more positive the evaluation of the influence of the media and the religious community on religious socialization, the stronger the monistic attitudes of our Christian students.

By and large Muslims show more and stronger associations with monism than Christians. Of the socio-cultural characteristics gender has the strongest association (.35). In line with general expectations, men (3.21) are clearly more monistic than women (2.51). This observation accords with the idea that women are more open to 'the other', that is adherents of other religions, than men. Urbanization again correlates positively with monism (.18); and Muslims who are acquainted with the local language, Tamil, score higher on monism than those who do not speak Tamil (mean scores 3.09 and 2.75 respectively). As for the socio-religious characteristics, we find that students who score relatively highly on monism evaluate the contribution of religious socializing agents as positive. These positive correlations apply to friends (.18), the religious community (.18), parents (.15) and teachers/professors (.14).

While our Hindu population scored relatively poorly on monism, Hindu women (1.67) disagree even more strongly with monism than Hindu men 
TABLE 5.5 Social location of monism among Christian, Muslim and Hindu students. Correlations (eta for the nominal variables sex and language; Pearson's $r$ for the other, ordinal variables) between monism and some personal characteristics.

\begin{tabular}{|c|c|c|c|}
\hline & Christians & Muslims & Hindus \\
\hline \multicolumn{4}{|c|}{ Socio-cultural characteristics } \\
\hline Age & & $.14^{*}$ & $.17^{* *}$ \\
\hline Sex & $.07^{*}$ & $.35^{* *}$ & $.17^{* *}$ \\
\hline Language & $.15^{* *}$ & $.17^{* *}$ & $.07^{*}$ \\
\hline Urbanization & $.11^{* *}$ & $.18^{* * *}$ & $-.19^{* *}$ \\
\hline \multicolumn{4}{|l|}{ Field of specialization } \\
\hline \multicolumn{4}{|c|}{ Socio-economic characteristics } \\
\hline Caste & & & $-.20^{* *}$ \\
\hline Education mother & & $-.13 *$ & $-.13^{* *}$ \\
\hline Education father & & & $-.18^{* *}$ \\
\hline \multicolumn{4}{|c|}{ Socio-religious characteristics } \\
\hline Parents & & $.15 *$ & $.09 *$ \\
\hline \multicolumn{4}{|l|}{ Relatives } \\
\hline Friends & & $.18^{* * *}$ & $.09 *$ \\
\hline Religious community & $.13^{* *}$ & $.18^{* *}$ & $.22^{* *}$ \\
\hline Teachers/professors & & $.14^{*}$ & $.13^{* *}$ \\
\hline Media & $.17^{* *}$ & & $.20^{* *}$ \\
\hline
\end{tabular}

All correlations are significant at $\mathrm{p}<.00$ level $\left(^{* *}\right)$ or $\mathrm{p}<.05$ level $\left({ }^{*}\right)$.

(1.93). But in contrast to the findings among Christians and Muslims, urbanization (-.19) correlates negatively with monism: Hindus who live in the countryside agree more with monism than those living in cities. Socio-economic characteristics also give some indications where we find (or do not find) monistic attitudes. In lower castes $(-.20)$ and among students whose parents are less educated (-.18 and -.13 respectively for father's and mother's education) monistic attitudes are more common. Finally, the correlations with socializing agents point in the same direction. Respondents who perceive the influence of these socializing agents as positive for their religious identity have higher scores on monism. This applies to their religious community (.22), the media (.20), teachers/professors (.13), parents (.og) and friends (.og) (Table 5.5). 
TABLE 5.6 Social location of commonality pluralism among Christian, Muslim and Hindu students. Correlations (eta for the nominal variables sex and language; Pearson's $r$ for the other, ordinal variables) between commonality pluralism and some personal characteristics.

\begin{tabular}{|c|c|c|c|}
\hline & Christians & Muslims & Hindus \\
\hline \multicolumn{4}{|c|}{ Socio-cultural characteristics } \\
\hline Age & $.08 *$ & & $-.16^{* *}$ \\
\hline Sex & $.13^{* *}$ & $.30^{* * *}$ & $.20^{* *}$ \\
\hline \multicolumn{4}{|l|}{ Language } \\
\hline Urbanization & $-.17^{* * *}$ & $-.21^{* *}$ & \\
\hline \multicolumn{4}{|l|}{ Field of Specialization } \\
\hline \multicolumn{4}{|c|}{ Socio-economic characteristics } \\
\hline Caste & & & $.19^{* *}$ \\
\hline Education mother & $-.15^{* *}$ & $.16 *$ & \\
\hline Education father & & $.14^{*}$ & \\
\hline \multicolumn{4}{|c|}{ Socio-religious characteristics } \\
\hline Parents & & $-.15 *$ & $.08 *$ \\
\hline Relatives & $.09 *$ & $-.15 *$ & \\
\hline Friends & & $-.17^{* *}$ & \\
\hline Religious community & & & $-.09 *$ \\
\hline Teachers/professors & & $-.13 *$ & \\
\hline Media & $-.11^{* *}$ & & \\
\hline
\end{tabular}

All correlations are significant at $\mathrm{p}<.00$ level $\left({ }^{* *}\right)$ or $\mathrm{p}<.05$ level $\left({ }^{*}\right)$.

Commonality Pluralism

For a detailed overview of correlations between commonality pluralism and personal characteristics of our Christian, Muslim and Hindu student population, see Table 5.6.

Christian students who agree more strongly with commonality pluralism have spent most of their lives in less urbanized areas like towns or villages (-.17), and their mothers have relatively low educational levels (-.15). Commonality pluralism also correlates negatively with the perception of a positive influence by media on religious socialization (-..11).

Among Muslim students women (3.20) agree significantly more strongly with commonality pluralism than men (2.69). Once again women are more open to other religions, for example in their agreement with the statement, "Religions reveal different aspects of the same ultimate truth". Like Christians, 
Muslims who agree more strongly with commonality pluralism come from less urbanized areas (-.21). Higher parental educational level is an indicator of agreement with commonality pluralism. Finally, commonality pluralism is more likely to be found among students who report less positive influence by socializing agents like friends (-.17), parents, relatives (-.15) and teachers/professors (-.13).

Hindu women, too, (3.51) agree significantly more strongly with commonality pluralism than Hindu men (3.21). Although the age range in our population is limited, younger students agree more strongly with commonality pluralism (.16). Among Hindus caste is an indicator of agreement. Commonality pluralism is more likely to be found among people belonging to categories like 'forward castes' and less likely to be supported by Hindus belonging to underprivileged classes like 'scheduled tribes and scheduled castes' and 'most backward castes' (.19).

\section{Differential Pluralism}

For differential pluralism significant correlations with some personal characteristics are confined to Christians and Hindus, but none of these correlations is above .20. Hence it is difficult to make general observations.

Among Christians degree of urbanization once again proves to be an indicator. Greater agreement with differential pluralism is found among Christians who lived most of their lives in less urbanized areas like towns or villages (-.19). Surprisingly, male college and university students (2.78) agree more strongly with differential pluralism than their female peers (2.50), although the association is rather weak (eta .14). Agreement with differential pluralism is also more likely among students whose mother (-.17) or father (-.12) has relatively little education. When the influence of socializing agencies such as mass media $(-.11)$ and the religious community $(-.09)$ is perceived as less positive there is greater agreement with differential pluralism.

Among Hindu students the levels of association are also low. But generally students agree that differences between religions are "part of God's plan to save the world" (item 13) and are "a basis for mutual enrichment and growth" (item 16) if they live in less urbanized areas (-.18); their parents are poorly educated (-.13); and if they perceive the influence of religious socialization by media (.14), teachers (.11) and religious community (.08) as positive. Remarkably (but understandably), these latter correlations point in the opposite direction to those among Christians. 
TABLE 5.7 Social location of differential pluralism among Christian, Muslim and Hindu students. Correlations (eta for the nominal variables sex and language; Pearson's $r$ for the other, ordinal variables) between differential pluralism and some personal characteristics. ${ }^{8}$

\begin{tabular}{|c|c|c|c|}
\hline & Christians & Muslims & Hindus \\
\hline \multicolumn{4}{|c|}{ Socio-cultural characteristics } \\
\hline Age & & & $.09 *$ \\
\hline Sex & $.14^{* *}$ & & \\
\hline Urbanization & $-.19^{* *}$ & & $-.18^{* *}$ \\
\hline \multicolumn{4}{|c|}{ Socio-economic characteristics } \\
\hline Education mother & $-.17^{* *}$ & & $-.13^{* *}$ \\
\hline Education father & $-.12^{* *}$ & & $-.12^{* *}$ \\
\hline \multicolumn{4}{|c|}{ Socio-religious characteristics } \\
\hline Friends & $.08 *$ & & \\
\hline Religious community & $-.09^{* *}$ & & $.08 *$ \\
\hline Teachers/professors & & & $.11^{* *}$ \\
\hline Media & $-.11^{* *}$ & & $.14^{* *}$ \\
\hline
\end{tabular}

All correlations are significant at $\mathrm{p}<.00$ level $(* *)$ or $\mathrm{p}<.05$ level $(*)$.

Research question 4: Which personal characteristics may be considered predictors of models of interpreting religious plurality among Christian, Muslim and Hindu students?

Since we include only personal characteristics that show relevant $(\mathrm{r} \geq .20)$ and significant $(\mathrm{p}<.000)$ correlations with our models of interpreting religious plurality, few independent variables were included in the regression analyses. While in the case of monism and commonality pluralism some personal characteristics meet this criterion in at least one of the religious groups, none of the personal characteristics showed relevant correlations for differential pluralism. Accordingly linear regression analyses were confined to monism and commonality pluralism.

For monism gender has the strongest predictive value, both among Muslims $(\beta-.36)$ and Hindus $(\beta-.19)$ : men score considerably higher on monistic attitudes than women. Next, the perceived positive influence of the religious community on religious socialization contributes to more exclusivist and inclusivist

8 The following characteristics did not show significant correlations for any of the groups of respondents: language, field of specialization, caste, socialization by parents and relatives. 
TABLE 5.8 Regression analyses for monism with weights $(\beta)$ for each variable and total explained variance $\left(R^{2}\right.$ and adjusted $\left.R^{2}\right)$ for Christian, Muslim and Hindu students separately.

\begin{tabular}{|c|c|c|c|}
\hline & Christians & Muslims & Hindus \\
\hline \multicolumn{4}{|l|}{ Socio-cultural characteristics } \\
\hline Sex (male 1; female 2) & .05 & $-.36^{* *}$ & $-.19^{* *}$ \\
\hline \multicolumn{4}{|l|}{ Socio-economic characteristics } \\
\hline Caste & .02 & .09 & $-.08 *$ \\
\hline \multicolumn{4}{|l|}{ Socio-religious characteristics } \\
\hline Religious community & $.09 *$ & $.14^{*}$ & $.16^{* *}$ \\
\hline Media & $.13^{* *}$ & -.01 & $.17^{* *}$ \\
\hline $\mathrm{R}^{2}$ & .04 & .16 & .11 \\
\hline Adj. $R^{2}$ & .03 & .14 & .11 \\
\hline
\end{tabular}

Standardised regression coefficients $(\beta)$ are significant at $\mathrm{p}<.00\left({ }^{* *}\right)$ or $\mathrm{p}<.05\left(^{*}\right)$ level.

attitudes ( $\beta .16$ for Hindus and $\beta .14$ for Muslims). In respect of Hindus, finally, the influence of the mass media is worth mentioning: when media contribute positively to religious socialization, at least in the respondent's perception, scores on monistic attitudes are more likely to be high $(\beta .17)$. Still, the overall explained variance is quite low: $14 \%\left(\right.$ Adj. $\mathrm{R}^{2}$ ) among Muslims and $11 \%$ (Adj. $\mathrm{R}^{2}$ ) among Hindus. Among Christian students there are hardly any statistically significant influences on monism, because the total explained variance for Christian students is so low.

In the case of commonality pluralism we limit ourselves to the 255 Muslims in our research sample. None of the selected socio-economic and socio-religious variables contributes significantly to the prediction of commonality pluralism. Gender and urbanization, which we categorized under socio-cultural personal characteristics, jointly account for $13 \%$ of the variance in commonality pluralism (Adj. $\mathrm{R}^{2}$ ). Gender is the strongest predictor $(\beta .31)$ and - not surprisingly - reverses the direction found in monism. Women score considerably higher on commonality pluralism than men. Urbanization $(\beta-.19)$ is a second predictor: if Muslim respondents have lived most of their lives in less urbanized areas, they can be expected to agree more strongly with commonality pluralism. In other words: living in cities, which are modern but religiously more diverse than the countryside, leads to less agreement with items like "Different religions reveal different aspects of the same ultimate truth" (item 7). 
TABLE 5.9 Regression analyses for commonality pluralism with weights $(\beta)$ for each variable and total explained variance $\left(R^{2}\right.$ and adjusted $\left.R^{2}\right)$ for Christian, Muslim and Hindu students separately.

\begin{tabular}{llll}
\hline & Christians & Muslims & Hindus \\
\hline $\begin{array}{lll}\text { Socio-cultural characteristics } \\
\text { Sex (male 1; female 2) }\end{array}$ & $-.10^{*}$ & .3 1** $^{* *}$ & $.18^{* *}$ \\
Urbanization & $-.15^{* *}$ & $-.19^{* *}$ & .04 \\
& & & .04 \\
& $\mathrm{R}^{2} .04$ & .14 & .03 \\
\hline
\end{tabular}

Standardised regression coefficients $(\beta)$ are significant at $\mathrm{p}<.00\left(^{* *}\right)$ or $\mathrm{p}<.05\left(^{*}\right)$ level.

\subsection{Findings and Discussion}

In this concluding section we highlight the salient features of our findings and consider some points for discussion in light of our research questions.

\subsubsection{Three Comparative Models of Interpreting Religious Plurality}

First, our research produced three reliable cross-religious comparative models of interpreting religious plurality: monism, commonality pluralism and differential pluralism. Although the conceptual framework was based on Christian theology (Knitter's classification), these models can be generalized to Muslims and Hindus as well. Although our comparative models sometimes underrepresent tendencies specific to particular religious traditions, they have enough substance for meaningful comparison. Similar empirical studies using concepts and models from Islamic and Hindu theology of religions could broaden the picture that we have outlined. Such a procedure would lead to a comparative theology that takes into account both emerging theoretical reflections and concrete religious experiences of people living in multi-religious contexts. ${ }^{9}$

The conflation of replacement monism and fulfilment monism into a single model suggests that, although replacement and fulfilment are theoretically

9 This type of empirical comparative theology is obviously different from the comparative theology of Clarke (1876) that entailed evaluation of religious traditions by Christian standards. But it also differs from the comparative theology of Clooney (2010) and Fredericks (1999), which is based on interreligious dialogue. 
distinguishable, their underlying perspective on religious pluralism is the same: monism. Previous research in Western contexts among specific religious groups also found an empirical clustering of exclusivist and inclusivist attitudes (Sterkens 2001; Ziebertz 2007; Vermeer \& Van der Ven 2004). In Tamil $\mathrm{Nadu}$, too, viewed from a cross-religious comparative perspective, the usefulness of the distinction between replacement (exclusivism) and fulfilment (inclusivism) proves to be limited. Christians display a kind of 'weak' monism, characterized by a tendency towards fulfilment. Among Hindus and Muslims in our research population replacement and fulfilment tendencies blend almost indistinguishably.

Our research also sheds some light on two distinctive pluralistic approaches to religious diversity: the first focusing on underlying common ground (commonality pluralism); the second stressing the value and richness of differences between religions (differential pluralism). Hence it would be more correct to speak of specific pluralism models than of pluralism in general. What complicates the interpretation of these models is that Hindus differ from Christians and Muslims in that they manifest a universalistic and relativistic tendency in commonality pluralism. This is not a defensive stance regarding Hinduism, but entails working towards a universal faith based on common elements. Hindu universalism allows tolerance of other religions and assimilating them in the process of transforming itself. Hinduism is seemingly more intent on the search for truth than on defending the truths it represents (Mukerji 1990, 233). For this reason Hinduism does not regard internal divisions and contrasting views among its adherents as threatening its existence. We realize that a conceptual framework based on Christian theology cannot fully reflect the Hindu perspective. Further research into this model could reveal a 'weak' and a 'strong' position in commonality pluralism, with Christians and Muslims representing the former and Hindus the latter. 'Strong' commonality pluralism may reflect a more universalistic and relativistic tendency.

It is noteworthy that relativistic pluralism does not emerge as separate comparative model. Does this mean that it should not be regarded as a separate model? Before drawing this conclusion, one should realize that among specific religious groups relativism could be found separately, but also that one 'relativistic item' (item 2) ended up in our comparative commonality pluralism model.

Empirical confirmation of three different models of interpreting religious plurality in the minds of young people living in a multi-religious context is an important finding. But we must note that the universalistic tendency in commonality pluralism was absent in our comparative model, and that the measurement of differential pluralism consists of only two items. 


\subsubsection{Cross-religious Differences in Models of Interpreting Religious Plurality}

The model that proves most acceptable to the three religious groups is commonality pluralism. In a traditionally multi-religious setting like Tamil Nadu commonality pluralism seems a natural choice. The most contested perspective among Muslims and Hindus is monism. Still, Muslim respondents agree with monism, whereas Christians are generally ambivalent. There are also significant differences between the religious traditions. Hindus not only express significantly stronger agreement with commonality pluralism than Christians and Muslims; they also differ significantly from the other two groups in disagreeing with monistic attitudes. For all religious groups the attitude towards differential pluralism is ambivalent. Although Hindus show more agreement than Christians and Muslims, there are no significant differences between groups.

\subsubsection{Social Location and Prediction of Models of Interpreting Religious Plurality}

Among Muslims and Hindus monism is more likely to be found among men than women. For Christians and Muslims monism is more likely to be found in urbanized areas, while among Hindus it features in less urbanized areas. Caste and parental educational levels of parents are relevant only for Hindus: greater agreement with monism when these indicators of socio-economic class are weak. Finally, monism is more likely when respondents evaluate the influence of agencies of religious socialization positively.

Among Muslims and Hindus women are more positive about commonality pluralism than men. Christians and Muslims support commonality pluralism mainly in less urbanized areas. Higher socio-economic levels are an indicator of greater agreement with commonality pluralism (among Muslims and Hindus). And finally, commonality pluralism is supported (especially by Muslims) when respondents evaluate the influence of agencies of religious socialization less positively.

The social location of differential pluralism is equivocal. Among Muslims we do not find any significant correlations at all. But the results for Christians and Hindus point in the same direction: differential pluralism is found in less urbanized areas and among pupils whose parents are less educated.

The tendency towards monism among Muslim (and to a lesser extent Hin$\mathrm{du}$ ) men and relatively more agreement with commonality pluralism among Muslim and Hindu women merits further scrutiny. Maybe this research finding can be explained by considering the difference in female and male self-concepts. If the self-identity of women is characterized by 'integration' and that of 
men by 'separateness', women should be more open to their social environment (Markus \& Oyserman 1989, 101). Integrated selves are more responsive to their social environment, which in Tamil Nadu is multi-religious. This explains Muslim women's stronger agreement with commonality pluralism (i.e. other religions reveal different aspects of the same ultimate reality/truth/liberation) and lesser agreement with monism (i.e. one's own religion is the only true religion). A question that still needs clarification is why this tendency is found only among Muslim and Hindu women and not among Christian women, at least in comparison to Christian men. We consider this question in the next chapter. 